University of Chicago Law School

Chicago Unbound

Journal Articles

Faculty Scholarship

1991

\title{
Justice Brennan and the Freedom of Speech: A First Amendment Odyssey
}

Geoffrey R. Stone

Follow this and additional works at: https://chicagounbound.uchicago.edu/journal_articles

Part of the Law Commons

\section{Recommended Citation}

Geoffrey R. Stone, "Justice Brennan and the Freedom of Speech: A First Amendment Odyssey," 139 University of Pennsylvania Law Review 1333 (1991).

This Article is brought to you for free and open access by the Faculty Scholarship at Chicago Unbound. It has been accepted for inclusion in Journal Articles by an authorized administrator of Chicago Unbound. For more information, please contact unbound@law.uchicago.edu. 


\section{JUSTICE BRENNAN AND THE FREEDOM OF SPEECH: A FIRST AMENDMENT ODYSSEY}

\section{GEOFFREY R. STONE†}

At the time of Justice William J. Brennan, Jr.'s appointment to the Supreme Court of the United States, first amendment doctrine was in its infancy. The Court had not yet addressed the issues of obscenity or libel, it had made only passing acquaintance with the complexities of commercial advertising and the concept of the public forum, it had not yet discovered the content-based/contentneutral distinction, its protection of subversive advocacy was more theoretical than real, and its overall free speech jurisprudence was rigid, simplistic, and incomplete. At the time of Justice Brennan's retirement some thirty-four years later, the Court's free speech doctrine was far richer, more subtle, and more speech-protective than ever before in our nation's history. Justice Brennan, it is fair to say, was the primary architect of this revolution in our understanding of the freedom of speech.

During his long tenure on the Court, Justice Brennan established himself as one of the staunchest defenders of the freedom of speech the Court has ever known. Of the 252 free speech decisions in which Justice Brennan participated, ${ }^{1}$ the Court accepted the free speech claim in 148 , or $59 \%$, of the cases. Justice Brennan accepted the free speech claim in 221 , or $88 \%$, of these cases. ${ }^{2}$ Thus, during

† Harry Kalven, Jr. Professor of Law and Dean, University of Chicago Law School. I would like to thank Joshua Davis for his excellent research assistance. I would also like to thank my colleagues Marcella David, Cass Sunstein, Dennis Hutchinson, and Abner Greene for their helpful comments.

1 This only includes cases decided with full opinions. It does not include, for example, the thirty-one decisions in the area of obscenity from 1967 to 1973 that were decided with only one line opinions. See, e.g., Walker v. Ohio, 398 U.S. 434 (1970) (per curiam) (reversing the Ohio Supreme Court in one sentence and citing only Redrup v. New York, 386 U.S. 767 (1967) (per curiam) (protecting the distribution of allegedly obscene publications under the cloak of the first amendment)).

2 Approximately one-half of the thirty-one cases in which Justice Brennan rejected the first amendment claim involved regulations designed to "improve" the marketplace of ideas, regulations of obscenity, or regulations of speech designed to promote competing interests of equality. See, e.g., Austin v. Michigan Chamber of Commerce, 110 S. Ct. 1391 (1990) (upholding state limitation on corporate political spending during elections); Board of Directors of Rotary Int'l v. Rotary Club of Duarte, 481 U.S. 537 (1987) (upholding state statute requiring Rotary Club to admit women); Roberts v. United States Jaycees, 468 U.S. 609 (1984) (upholding state statute requiring admission of women to Jaycees group); First Nat'l Bank of Boston 
his thirty-four years on the Court, Brennan was 50\% more likely than the Court as a whole to protect the freedom of speech. ${ }^{3}$ Moreover, in only two cases from 1956 to 1990 did Justice Brennan reject a free speech claim that the Court accepted, and these were both cases in which the regulation of free expression was designed to "improve" the marketplace of ideas. ${ }^{4}$ This is a remarkable record, indeed. In this Essay, I will trace a few of the many highlights of Justice Brennan's extraordinary first amendment odyssey.

The portrayal of sex ... is not itself sufficient reason to deny material the constitutional protection of freedom of speech and press. ... Sex, a great and mysterious motive force in human life, has indisputably been a subject of absorbing interest to mankind through the ages. ${ }^{5}$

The Supreme Court first addressed the issue of obscenity in Roth $v$. United States. ${ }^{6}$ Roth was decided during Justice Brennan's

v. Bellotti, 435 U.S. 765 (1978) (joining White's dissent which criticizes the Court's striking down a state statute which restricted corporate spending in referendum elections); United States v. Thirty-Seven Photographs, 402 U.S. 363 (1971) (upholding federal statute allowing customs agents to seize obscene materials); Roth v. United States, 354 U.S. 476 (1957) (upholding state obscenity statute).

The other one-half of these cases are scattered throughout the entire corpus of first amendment law. See, e.g., Bethel School Dist. No. 403 v. Fraser, 478 U.S. 675 (1986) (upholding a suspension for student profanity in high school); Regan v. Taxation with Representation of Washington, 461 U.S. 540 (1983) (denying tax exemptions to politically active organizations); New York v. Ferber, 458 U.S. 747 (1982) (upholding child pornography statute); United States Postal Serv. v. Council of Greenburgh Civic Ass'ns, 453 U.S. 114 (1981) (upholding restriction on use of mailboxes for unstamped materials); Hutchinson v. Proxmire, 443 U.S. 111 (1979) (criticizing, in dissent, the Court's refusal to grant libel immunity to certain statements of a senator); Friedman v. Rogers, 440 U.S. 1 (1979) (sustaining state prohibition on use of trade names by optometrists); Procunier v. Navarette, 434 U.S. 555 (1978) (upholding censorship of prisoners' outgoing mail); NLRB v. Gissel Packing Co., 395 U.S. 575 (1969) (upholding federal labor law prohibiting employer threats against employees for union organizing); United States v. O'Brien, 391 U.S. 367 (1968) (upholding federal law criminalizing draft card burning).

3 It is noteworthy that, although the percentage of cases in which Justice Brennan voted to uphold the free speech claim remained essentially the same in the first and second halves of his tenure (87\% in the first half vs. $88 \%$ in the second half), the Court as a whole upheld $85 \%$ the free speech claims from 1956 to 1973 , but only $51 \%$ from 1973 to 1990.

${ }^{4}$ See Federal Election Comm'n v. National Conservative Politcal Action Comm., 470 U.S. 480 (1985); First Nat'l Bank of Boston v. Bellotti, 435 U.S. 765 (1978).

${ }^{5}$ Roth v. United States, 354 U.S. 476,487 (1957).

654 U.S. 476 (1957). 
first term on the Court, and it was his first opinion for the Court in a case involving the freedom of speech. It was an opinion he would come to regret.

The central holding in Roth was that "obscenity is not within the area of constitutionally protected speech or press. ${ }^{77}$ This holding was premised upon four critical judgments. First, in a passage that fully anticipated Robert Bork's philosophy of original intent, Brennan reviewed the status of obscenity at the time the Constitution was adopted and concluded that "there is sufficiently contemporaneous evidence to show that obscenity ... was outside the protection intended for speech and press." 8 Second, Brennan invoked "the universal judgment that obscenity should be restrained, reflected in the international agreement of over 50 nations, in the obscenity laws of all of the 48 States, and in the 20 obscenity laws enacted by the Congress from 1842 to $1956 .^{n 9}$ Third, embracing the "two-level" theory of Chaplinsky v. New Hampshire $^{10}$ and Beauharnais v. Illinois, ${ }^{11}$ Brennan concluded that, because obscenity is one of the "well-defined and narrowly limited classes of speech, the prevention and punishment of which have never been thought to raise any Constitutional problem," 12 it may be restricted "without proof either that ... [it] will perceptibly create a clear and present danger of antisocial conduct, or will probably induce its recipients to such conduct. ${ }^{\text {n13 }}$ Finally, Brennan rejected the argument that "obscenity" is too imprecise a concept to meet constitutional standards, declaring that all the Constitution requires "is that the language "conveys sufficiently definite warning as to the proscribed conduct when measured by common understanding and practices, ${ }^{\prime 14}$ and that the existence of "marginal cases in which it is difficult to determine the side of the line on which a particular fact situation falls is no sufficient reason to hold the language too ambiguous. ${ }^{15}$

7 Id. at 485 .

$8 \mathrm{Id}$. at 483 .

${ }^{9}$ Id. at 485 (citations omitted).

${ }^{10} 315$ U.S. 568 (1942).

11343 U.S. 250 (1952).

${ }^{12}$ Roth, 354 U.S. at 485 (quoting Chaplinsky v. New Hampshire, 315 U.S. 568, 571-72 (1942)).

13 Id. at 486 (footnotes omitted).

14 Id. at 491 (quoting United States v. Petrillo, 332 U.S. 1, 7-8 (1947)).

$15 \mathrm{Id}$. at $491-92$ (quoting Petrillo, 332 U.S. at 7). 
Brennan's casual reading of original intent, his uncritical acceptance of the significance of consensus, his embrace of the notion that "obscenity" is "unprotected" because it is "without redeeming social importance," and his cavalier dismissal of concerns about vagueness all reflected the dominant free speech jurisprudence of the time. Anticipating later developments, Brennan did observe in Roth that the "fundamental freedoms of speech and press have contributed greatly to the development and well-being of our free society" and that "[c]easeless vigilance" is therefore "the watchword to prevent their erosion. ${ }^{" 16}$ But in articulating the four critical judgments noted above, Brennan effectively eschewed such vigilance and embraced a highly formalistic, originalist, and wooden approach to first amendment analysis. The following year, Justice Brennan would help set in motion a jurisprudential revolution that eventually would call all these judgments into question. In Roth, though, Brennan got the revolution off to a limping start, indeed.

To deny an exemption to [those] who engage in certain forms of speech is in effect to penalize them for such speech. . . . The [State is] plainly mistaken in [its] argument that, because a tax exemption is a "privilege" . . its denial may not infringe speech. ${ }^{17}$

During the post-World War II "cold war" era, fears over national security generated wide-ranging federal, state, and local restrictions on "radical" speech. These restrictions included the extensive use of loyalty oaths, emergency detention programs, attempts to "outlaw" the Communist Party, requirements that communist-front and communist action organizations register with the government, legislative investigations of suspected "subversives," direct criminal prosecutions, and the denial of employment and other governmental "benefits" to individuals who were not "loyal" to the United States.

At the time Justice Brennan joined the Court, such programs were aggressively enforced at all levels of government and the nation was consumed with its effort to suppress subversive expression. Prior to Brennan's appointment, the Court did not take a strong stand in defense of the freedom of speech in the face of this powerful anticommunist campaign. In American Communications

${ }^{16} I d$. at 488 .

${ }^{17}$ Speiser v. Randall, 357 U.S. 513, 518 (1958). 
Association v. Douds, ${ }^{18}$ for example, the Court upheld section 9(h) of the Labor-Management Relations Act of 1947, which prohibited the National Labor Relations Board from enforcing employee representation rights of any labor union whose officers failed to execute affidavits that they were not members of the Communist Party. In Adler $v$. Board of Education, ${ }^{19}$ the Court upheld a New York law prohibiting any person who joined any organization that advocated the violent overthrow of the government, with knowledge of the organization's advocacy, from teaching in any public school. And, in Dennis v. United States, ${ }^{20}$ the Court upheld the convictions of the leaders of the Communist Party of the United States under the Smith Act, which prohibited any person to "advocate ... the duty, necessity, desirability, or propriety of overthrowing or destroying any government in the United States by force or violence. ${ }^{n 1}$

The abuses and overreaching of this era had a profound effect on Justice Brennan's understanding of the freedom of speech. In the eye of this anticommunist hurricane, Brennan first sketched out the contours of his unique contribution to our first amendment jurisprudence.

A central feature of the anticommunist program was the denial of government employment and other benefits to "subversives." In upholding such restrictions, the pre-Brennan Court frequently relied upon the so-called "right/privilege" distinction. This doctrine held that government constitutionally could withhold benefits from individuals who engaged in constitutionally protected expression, for which they could not be criminally punished, because the individuals had no "right" to the "privilege" itself. In Barsky v. Board of Regents, ${ }^{22}$ for example, the Court invoked this distinction in upholding the suspension of a physician's medical license because of events arising out of his communist affiliations. Four years later, Justice Brennan's opinion for the Court in Speiser v. Randall ${ }^{23}$ emphatically rejected the right/privilege distinction.

Speiser involved a California law that established a special property tax exemption for veterans, but it denied the exemption

\footnotetext{
18399 U.S. 382 (1950).

19342 U.S. 485 (1952).

20341 U.S. 494 (1951).

21 Id. at 496.

22347 U.S. 442 (1954).

23357 U.S. 513 (1958).
} 
to any veteran who advocated the violent overthrow of the government. Brennan rejected the state's argument that the disqualification was lawful because it merely withheld a "privilege." Brennan explained that " $[t]$ o deny an exemption to claimants who engage in certain forms of speech is in effect to penalize them for their speech," because the "deterrent effect is the same as if the State were to fine them for this speech." 24 Thus, Brennan concluded, the state was "plainly mistaken" in its "argument that, because a tax exemption is a 'privilege' . . . its denial may not infringe speech."

Brennan's rejection of the right/privilege distinction in Speiser was a critical step in the evolution of first amendment doctrine, but it did not end the case. Brennan proceeded in Speiser to articulate a second-and equally important-principle of first amendment jurisprudence. Turning to the procedure mandated by the California law, Brennan held that the statute violated the first amendment because it required the applicant to prove that he had not advocated the violent overthrow of government. Brennan observed that " $[t]$ he vice of the present procedure is that, where particular speech falls close to the line separating the lawful and the unlawful, the possibility of mistaken factfinding-inherent in all litigation-will create the danger that the legitimate utterance will be penalized." 26 Moreover, such an allocation of the burden of proof effectively could chill free expression since " $[t]$ he man who knows that he must bring forth proof and persuade another of the lawfulness of his conduct necessarily must steer far wider of the unlawful zone than if the State must bear these burdens." 27

Unlike Brennan's first foray into first amendment jurisprudence in Roth, which embodied a cautious, formalistic, and tradition-bound approach, his second foray, in Speiser, revealed an impressive willingness to question accepted first amendment doctrine in the light of a more speech-protective conception of the freedom of speech. Moreover, in stark contrast with his opinion in Roth, Brennan's effort in Speiser, inspired by the political and historical realities of the era, displayed an extraordinary sensitivity to the procedures by which government regulates free expression. This special emphasis on procedure, which would play a pivotal role in subsequent decisions limiting government efforts to suppress

${ }^{24} I d$. at 518.

${ }^{25} I d$.

26 Id. at 526.

${ }^{27}$ Id. 
subversive advocacy, ${ }^{28}$ was to become a hallmark of Justice Brennan's first amendment jurisprudence.

We cannot close our eyes to the fact that the militant Negro civil rights movement has engendered the intense resentment and opposition of the politically dominant white community of Virginia; litigation assisted by the NAACP has been bitterly fought. In such circumstances, a statute broadly curtailing group activity leading to litigation may easily become a weapon of oppression. ${ }^{29}$

Justice Brennan's understanding of the freedom of speech was influenced, not only by government efforts to suppress communism, but by the civil rights movement as well. One of the most distinctive features of this movement was its attempt to enlist the support of the federal courts in the protection of federal constitutional rights through a carefully orchestrated strategy of systematic litigation. As Harry Kalven once observed, this effort was designed "to trap democracy in its own decencies." To a South hostile to Brown v. Board of Education, ${ }^{31}$ the NAACP "appeared, and accurately, as a militant army led by lawyers determined to see to it that 'all deliberate speed' [had] some meaning." 32

Prior to Brown, the State of Virginia had made no effort to restrict the litigation activities of the NAACP. Shortly after Brown, however, Virginia, Arkansas, Florida, Georgia, Mississippi, South Carolina, and Tennessee all enacted legislation that expressly prohibited any organization to retain a lawyer in connection with litigation to which it was not a party and in which it had no pecuniary right or liability. ${ }^{33}$ Such legislation would effectively have crippled the efforts of the NAACP to enforce the mandate of Brown.

${ }^{28}$ See, e.g., Keyishian v. Board of Regents, 385 U.S. 589 (1967) (invalidating a New York law prohibiting school teachers from uttering "seditious" words); Cramp v. Board of Pub. Instruction, 368 U.S. 278 (1961) (invalidating on grounds of vagueness a Florida loyalty oath for teachers); Shelton v. Tucker, 364 U.S. 479 (1960) (invalidating an Arkansas statute requiring teachers to list every organization in which they held memberships as a condition of employment).

${ }_{29}$ NAACP v. Button, 371 U.S. 415, 435-36 (1968) (citations omitted).

${ }^{30}$ H. KALVEN, THE NegRo AND THE FirST AMENDMENT 67 (1965).

${ }^{31} 347$ U.S. 483 (1954).

32 H. RALVEN, supra note 30 , at 69 .

33 See Button, 371 U.S. at 445 (Douglas, J., concurring). 
In NAACP v. Button, ${ }^{34}$ the Court, in an opinion by Justice Brennan, held such legislation invalid as applied to the NAACP. Brennan rejected the contention that "solicitation' is wholly outside the area of freedoms protected by the First Amendment" because "a State cannot foreclose the exercise of constitutional rights by mere labels." ${ }^{35}$ Brennan explained that "[i]n the context of NAACP objectives, litigation is not a technique of resolving private differences; it is a means for achieving . . . equality of treatment . . . for the members of the Negro community." stances, litigation is "a form of political expression" and "[g]roups which find themselves unable to achieve their objectives through the ballot frequently turn to the courts." 37 For these groups that the NAACP assists, "litigation may be the most effective form of political association." $\$ 8$

By bringing litigation within the ambit of first amendment protection, Brennan's opinion in Button highlighted the central role of the courts as effective instruments of political and social change and, at the same time, empowered organizations like the NAACP to pursue aggressively the vindication of constitutional rights.

Moreover, in invalidating the Virginia legislation, Brennan elaborated on his concern, first enunciated in Speiser, that the Court must take special care to scrutinize the procedures by which government regulates free expression. Indeed, it was in Button that Brennan first coined the phrase "overbreadth," and it was in Button that Brennan gave impetus to the nascent first amendment vagueness doctrine. Building explicitly upon Speiser, Brennan explained that the "objectionable quality of vagueness and overbreadth" derives from "the danger of tolerating, in the area of First Amendment freedoms, the existence of a penal statute susceptible of sweeping and improper application." ${ }^{n 9}$ Because "[t]hese freedoms are delicate and vulnerable," the "threat of sanctions may deter their exercise almost as potently as the actual application of sanctions," 40 and "[b]ecause First Amendment freedoms need breathing space to survive, government may regulate in the area only with narrow specificity." 41 These themes of "overbreadth,"

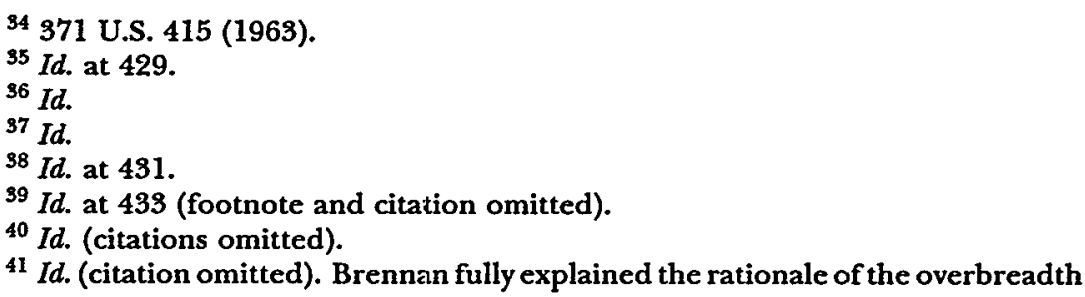


"vagueness," "chilling effect," "breathing space," and "narrow specificity," first clearly articulated by Brennan in Button, would come to dominate the evolution of first amendment jurisprudence for the next quarter century.

[W] consider this case against the background of a profound national commitment to the principle that debate on public issues should be uninhibited, robust, and wide-open, and that it may well include vehement, caustic, and sometimes unpleasantly sharp attacks on govermment and public officials. ${ }^{42}$

In New York Times v. Sullivan, ${ }^{43}$ Justice Brennan's most prominent first amendment opinion, the Court for the first time considered the extent to which the freedom of speech limits the award of damages in a libel action brought by public officials against critics of their official conduct. Sullivan, an elected Commissioner of the City of Montgomery, Alabama, brought a civil libel action against four black clergymen and The New York Times alleging that he had been libeled by statements in a full-page advertisement that described the civil rights movement in the South and concluded with an appeal for funds. The trial judge submitted the case to the jury under instructions that a public official was entitled to recover damages for defamatory statements unless the speaker could prove that the statements were true. Under these instructions, the jury returned a judgment for Sullivan in the amount of $\$ 500,000$.

The Supreme Court reversed, holding that the rule of law applied by the Alabama court violated the first amendment. At the outset, Justice Brennan confronted the Court's own past declarations, including Brennan's own pronouncement in Roth, that libel, one of the "well-defined and narrowly limited classes of speech, the

doctrine in his opinion for the Court in Gooding v. Wilson, 405 U.S. 518 (1972):

[T]he transcendent value to all society of constitutionally protected expression is deemed to justify allowing "attacks on overly broad statutes with no requirement that the person making the attack demonstrate that his own conduct could not be regulated by a statute drawn with the requisite narrow specificity." This is deemed necessary because persons whose expression is constitutionally protected may well refrain from exercising their rights for fear of criminal sanctions provided by a statute susceptible of application to protected expression.

Id. at 521 (citations omitted) (quoting Dombrowski v. Pfister, 380 U.S. 479, 486 (1965)).

12 New York Times v. Sullivan, 376 U.S. 254, 270 (1964) (citations omitted).

43 376 U.S. 254 (1964). 
prevention and punishment of which have never been thought to raise any Constitutional problem, ${ }^{44}$ is not "within the area of constitutionally protected speech. ${ }^{45}$ In rejecting these past declarations, Brennan expressly invoked his own rejection of the "solicitation" label in Button and explained that "we are compelled by neither precedent nor policy to give any more weight to the epithet 'libel' than we have to other 'mere labels' of state law." Indeed, like "the various other formulae for the repression of expression that have been challenged in this Court, libel can claim no talismanic immunity from constitutional limitations. ${ }^{n 77}$ To the contrary, libel "must be measured by standards that satisfy the First Amendment." 48

Turning to the task of articulating these standards, Brennan observed in an oft-quoted passage that "we consider this case against the background of a profound national commitment to the principle that debate on public issues should be uninhibited, robust, and wide-open. ${ }^{49}$ Drawing upon history in a quite different way than he drew upon history in Roth, Brennan analogized the civil law of libel, as applied by the Alabama court, to the Sedition Act of 1798 , which had been invalidated "in the court of history" because of the restraint it "imposed upon criticism of government and public officials. ${ }^{50}$

The essential difficulty, Brennan explained, is that "erroneous statement is inevitable in free debate," and even false statements of fact must therefore "be protected if the freedoms of expression are to have the 'breathing space' that they 'need ... to survive."'51 Thus, the Alabama rule of law could not be "saved by its allowance of the defense of truth," for a "rule compelling the critic of official conduct to guarantee the truth of all of his factual assertions" would lead to intolerable "self-censorship." 52 Echoing Speiser, Brennan observed that, under such a rule, "would-be critics of official conduct may be deterred from voicing their criticism, even though

44 Chaplinsky v. New Hampshire, 315 U.S. 568, 571 (1942), quoted in Roth v. United States, 354 U.S. 476, 485 (1957).

45 Beauharnais v. Illinois, 343 U.S. 250, 266 (1952), quoted in Roth, 354 U.S. at 486.

${ }^{46}$ New York Times, 376 U.S. at 269 (citation omitted).

47 Id.

$48 \mathrm{Id}$.

${ }^{49} I d$. at 270 .

${ }^{50} I d$. at 276.

51 Id. at 271-72 (quoting NAACP v. Button, 371 U.S. 415, 433 (1963)).

52 Id. at 278-79. 
it is believed to be true and even though it is in fact true, because of doubt whether it can be proved in court or fear of the expense of having to do so." 53 Such a rule, Brennan added, "dampens the vigor and limits the variety of public debate. ${ }^{54}$ With these considerations in mind, Brennan concluded that public officials may not recover damages for defamatory falsehood relating to their official conduct unless they can prove "that the statement was made ... with knowledge that it was false or with reckless disregard of whether it was false or not." 55

Brennan's opinion in New York Times revolutionized the law of libel and, perhaps more important, signalled a critical shift in our first amendment jurisprudence. Indeed, the distance Justice Brennan-and the Court-had traversed in the seven years from Roth to New York Times is simply stunning. All four of the judgments that made up the core of Brennan's opinion in Roth were effectively reversed in New York Times.

In Roth, Brennan gave great weight to the "originalist" conclusion that, at the time the first amendment was adopted, "obscenity ... was outside the protection intended for speech and press. ${ }^{566}$ In New York Times, however, Brennan gave no weight to the "originalist" view, despite his observation in Roth that "[a]t the time of the adoption of the First Amendment" the law of libel was even more "fully developed" than the law of obscenity. ${ }^{57}$ In Roth, Brennan gave great weight to the fact that every state restricted the expression of obscenity. In New York Times, however, Brennan gave no weight to the analogous "consensus" about libel. In Roth, Brennan embraced the Chaplinsky-Beauharnais "two-level" theory and held that, because obscenity was "unprotected" by the first amendment, no further constitutional scrutiny was warranted. In New York Times, however, Brennan dismissed the invocation of "the epithet "libel" and insisted that "libel can claim no talismanic immunity from constitutional limitations. " 58 Finally, in Roth, Brennan gave short shrift to the claim that the concept of obscenity is too imprecise to meet constitutional standards. In New York Times, however, Brennan expanded upon his observations in Speiser about burdens of proof

53 Id. at 279.

${ }^{54} I d$.

${ }^{55}$ Id. at $279-80$.

${ }^{56}$ Roth, 354 U.S. at 483.

${ }^{57} I d$.

58376 U.S. at 269. 
and precision of regulation and his reflections in Button about "breathing space" and "chilling effects," to fashion a more sensitive, less formulaic, and more speech-protective mode of first amendment analysis.

New York Times did not, of course, "solve" the libel puzzle, for it left many important questions unanswered. What New York Times did do, however, was to take the essential first step in the effort to adjust in an appropriate and sensitive manner the inherently conflicting interests in individual reputation and the freedom of speech. Moreover, by abandoning the strict "two-level" theory of "protected" and "unprotected" expression, Brennan's opinion in New York Times ushered in a new era of first amendment doctrine in which the Court, freed from the rigid constraints of the past, has been able to adopt a more flexible mode of analysis to deal with a broad range of "low value" expression. ${ }^{59}$ Finally, by locating "the central meaning of the First Amendment ${ }^{260}$ in the controversy over seditious libel, Brennan's opinion in New York Times identified "a core protection of speech without which democracy cannot function" and thus put the "theory of the freedom of speech clause ... right side up for the first time. ${ }^{\prime 61}$ As Alexander Meiklejohn and Harry Kalven observed, the decision in New York Times was truly an "occasion for dancing in the streets." "62

New York Times cannot be fully understood without recognizing that it was driven, not only by concerns about free expression, but also, like Button, by the unique historical circumstances in which it arose. Like other devices designed to obstruct the civil rights movement, the $\$ 500,000$ libel judgment against the Times and the black clergymen who sponsored the advertisement was designed to dampen the drive for civil rights. Indeed, if the Alabama jury's massive damage award had been sustained on the basis of the technical inaccuracies involved in the dispute, then no person or institution would have felt free to challenge racial segregation in the South. New York Times, one of the most important decisions in the history of the first amendment, was thus not only a triumph for free expression; it was a triumph for civil rights and racial equality as well.

${ }^{59}$ See Stone, Content-Neutral Restrictions, 54 U. CHI. L. REV. 46, 47-48 (1987).

${ }^{60}$ New York Times, 376 U.S. at 273.

${ }^{61}$ Kalven, The New York Times Case: A Note on "The Central Meaning of the First Amendment," 1964 SUP. Cr. REV. 191, 208.

${ }^{62} \mathrm{Id}$. at 222 n. 125 . 
I am convinced that the approach initiated 16 years ago in [Roth] .. . cannot bring stability to this area of the law without jeopardizing fundamental First Amendment values, and I have concluded that the time has come to make a significant departure from that approach. ${ }^{63}$

In the years between Roth and Paris Adult Theatre I v. Slaton, ${ }^{64}$ the Court handed down more than forty decisions dealing with the issue of obscenity. ${ }^{65}$ During this era, at least five sharply distinct definitions of obscenity emerged within the Court, no one of which commanded a majority. Moreover, the breakdown of consensus was compounded by disagreement over such issues as pandering and "variable" obscenity. ${ }^{66}$ By 1967 , the breakdown was so complete that the Court took to deciding cases with one sentence orders that simply announced the judgment of the Court. ${ }^{67}$ After sixteen years of such "experimentation and debate," Justice Brennan finally reached the conclusion in his dissenting opinion in Paris Adult Theatre that "we are manifestly unable to describe [obscenity] except by reference to concepts so elusive that they fail to distinguish clearly between protected and unprotected speech. ${ }^{968}$ Brennan thus conciuded that "the outright suppression of obscenity cannot be reconciled with the fundamental principles" of the first amendment. 69

Building upon his opinion in Speiser, Brennan observed that although "sensitive tools" must "be used to carry out the 'separation of legitimate from illegitimate speech," in this context the Court had failed "to provide 'sensitive tools' to separate obscenity from other sexually oriented but constitutionally protected

${ }^{63}$ Paris Adult Theatre I v. Slaton, 413 U.S. 49, 73-74 (1973) (Brennan, J., dissenting).

64413 U.S. 49 (1973). On the same day that the Court decided Paris Adult Thealre, it also decided Miller v. California, 413 U.S. 15 (1973).

${ }^{65}$ For an overview of these decisions, see G. STONe, L. SeIDMan, C. Sunstein \& M. TUSHNET, CoNSTIrUTIONAL LAW 1120-24, 1141-45 (1986).

66 See, e.g., Ginsberg v. New York, 390 U.S. 629 (1968) (upholding a prohibition on the sale of pornography to children); Mishkin v. New York, 383 U.S. 502 (1966) (upholding convictions for obscenity of those who sold materials which were sadomasochistic); Ginzburg v. United States, 383 U.S. 463 (1966) (applying Roth standards to pandering).

${ }^{67}$ From 1967 to 1973 , some thirty-one cases were disposed of in this manner. See, e.g., Walker v. Ohio, 398 U.S. 434 (1970) (per curiam) (citing only Redrup v. New York, 386 U.S. 767 (1967) (per curiam)).

${ }^{68}$ Paris Adult Theatre, 413 U.S. at 84 (Brennan, J., dissenting).

${ }^{69} \mathrm{Id}$. at 83. 
speech. ${ }^{770}$ Indeed, Brennan reasoned, the concept of obscenity is so inherently vague that it "cannot be defined with sufficient specificity and clarity to provide fair notice to persons who create and distribute sexually oriented materials, to prevent substantial erosion of protected speech as a byproduct of the attempt to suppress unprotected speech, and to avoid very costly institutional harms." 71 In such circumstances, "we must scrutinize with care the state interest that is asserted to justify the suppression. For in the absence of some very substantial interest in suppressing such speech, we can hardly condone the ill effects that seem to flow inevitably from the effort."72 The lessons of Speiser, Button, and New York Times are plainly evident in Justice Brennan's Paris Adult Theatre dissent.

Turning to the task of scrutinizing the state interest, Brennan explained that "[b]ecause we assumed-incorrectly, as experience has proved-that obscenity could be separated from other sexually oriented expression without significant costs, ... we had no occasion in Roth to probe the asserted state interest in curtailing sexually oriented speech. ${ }^{73}$ Putting aside "the state interests in protecting children and in protecting unconsenting adults, ${ }^{n 74}$ Brennan observed that society's more generalized interests in suppressing obscenity remain "essentially unfocused and ill defined" and are "predicated on unprovable ... assumptions about human behavior, morality, sex, and religion." ${ }^{75}$ Because such assumptions "cannot validate a statute that substantially undermines the guarantees of the First Amendment, ${ }^{, 76}$ Brennan concluded that, "at least in the absence of distribution to juveniles or obtrusive exposure to unconsenting adults, ${ }^{777}$ government cannot constitutionally attempt "wholly to suppress sexually oriented materials on the basis of their allegedly 'obscene' contents. ${ }^{n 78}$

In abandoning his position in Roth, Brennan demonstrated the extent to which the Court itself is a "marketplace of ideas" in which conclusions are always tentative and open to reexamination in the

${ }^{70}$ Id. at 79 (quoting Speiser v. Randall, 357 U.S. 513, 525 (1958)).

71 Id. at 103 .

72 Id.

${ }^{73}$ Id. at 105.

${ }^{74} I d$. at 106.

${ }^{75} I d$. at 109 (footnote omitted).

$76 \mathrm{Id}$. at $109-10$.

$77 \mathrm{Id}$. at 113 .

${ }^{78} \mathrm{Id}$. 
light of new evidence and changed circumstances. Moreover, in adhering to his Paris Adult Theatre dissent for the remainder of his tenure, ${ }^{79}$ Brennan also demonstrated his personal commitment to the proposition that "the best test of truth is the power of the thought to get itself accepted in the competition of the market," for he recognized that the Court's rejection of his position was itself only provisional. If his colleagues continued to confront this view, they, too, might eventually see the error of their ways.

[W]ith the rigid characterization of a given locale as not a public forum, there is a danger that certain forms of public speech at the locale may be suppressed, even though they are basically compatible with the activities otherwise occurring at the locale. ${ }^{81}$

At the time Justice Brennan joined the Court, public forum doctrine was still in its infancy. ${ }^{82}$ Although the Court had recognized a rudimentary right of individuals to speak in public streets and parks, subject to reasonable regulation of time, place, and manner, it had not yet addressed the issues involved in access to other forms of public property. This was an issue that captured Justice Brennan's energy and attention through most of his tenure. It was an issue on which he was all too often on the losing side.

Because the formative decisions of the 1930s and 1940s predicated the right to a public forum on the fact that streets and parks had been used "time out of mind" for speech purposes, ${ }^{83}$ they carried the implication that there exists no first amendment right to use other forms of public property for such purposes. The implication, in other words, was that access to such property for speech purposes could be denied absolutely upon the state's naked assertion of title. Not surprisingly, then, in one of the first

79 See, e.g., Randall Book Corp. v. Maryland, 464 U.S. 919, 919 (1983) (Brennan, $\mathrm{J}$, dissenting from order denying certiorari) (urging state court to review a conviction for the sale of sadomasochistic materials); FCC v. Pacifica Found., 438 U.S. 726, 767 (1978) (Brennan, J., dissenting) (criticizing the majority's acceptance of diction restrictions on radio broadcasts); McKinney v. Alabama, 424 U.S. 669, 678 (1976) (Brennan, J., concurring and dissenting) (reversing conviction for selling obscene materials).

${ }^{80}$ Abrams v. United States, 250 U.S. 616, 630 (1919) (Holmes, J., dissenting).

${ }^{81}$ Greer v. Spock, 424 U.S. 828, 860 (1976) (Brennan, J., dissenting).

82 See generally Stone, Fora Americana: Speech in Public Places, 1974 SUP. CT. REV. 233 (elucidating the early developments of the public forum doctrine).

${ }^{83}$ See Hague v. CIO, 307 U.S. 496, 515-16 (1939) (Roberts, J., concurring); see also Schneider v. State, 308 U.S. 147, 163 (1939) (stating that "the streets are natural and proper places for the dissemination of information and opinion"). 
decisions to address this issue after Brennan's appointment, the Court, over Brennan's dissent, proclaimed that "[ $t]$ he State, no less than a private owner of property, has power to preserve the property under its control for the use to which it is lawfully dedicated. ${ }^{84}$

In case after case throughout his tenure, Brennan argued for a more expansive vision of the right to a public forum. In Greer $v$. Spock, ${ }^{85}$ for example, Brennan dissented from the Court's holding that a military base could constitutionally exclude all political activity, including speeches and leafleting, from the public areas of the base. Although conceding that the military could "exclude civilian traffic" entirely, Brennan maintained that it "could not choose freely to admit all such traffic save for the traffic in ideas. $" 86$ Brennan rejected the contention that the challenged restriction could be justified by references to "the national defense," for "if the recent lessons of history mean anything, it is that the First Amendment does not evaporate with the mere intonation of interests such as national defense, military necessity, or domestic security. ${ }^{87}$ Recalling New York Times, Brennan reminded the Court that such "interests 'cannot be invoked as a talismanic incantation to support any exercise of ... power." 88 Finally, Brennan rejected the Court's argument that the interest in "military neutrality" could justify the restriction, for "it borders on casuistry to contend that by even-handedly permitting public expression to occur in unrestricted portions of a military installation, the military will be viewed as sanctioning the causes there espoused. ${ }^{.89}$

Similarly, in Heffron v. International Society for Krishna Consciousness, ${ }^{90}$ Brennan dissented from the Court's holding that a state fair could constitutionally prohibit political and religious groups from distributing literature on the grounds of the fair, other than from preassigned, rented booths. Brennan observed that this restriction "sharply limit[s] the number of fairgoers to whom the proselytizers and candidates can communicate their messages" and thus "constitutes a significant restriction on First Amendment rights." 91

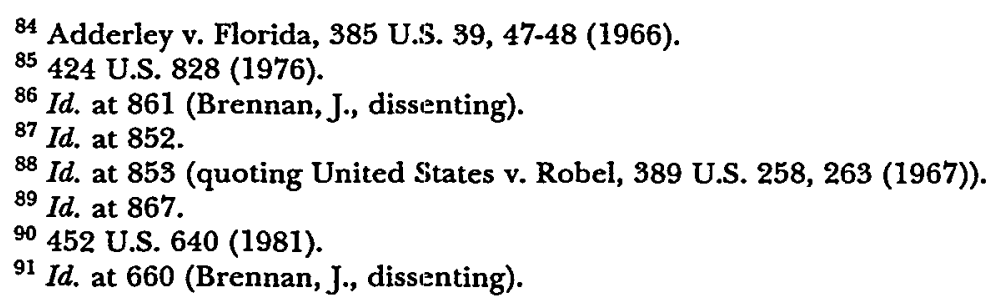


Unlike the Court, which readily accepted the contention that "if fairgoers are permitted to distribute literature, large crowds will gather, blocking traffic lanes and causing safety problems, "92 Brennan pointed out that the fair officials had "failed to provide any support for these assertions" and had made "no showing that relaxation of the booth Rule would create additional disorder in a fair that is already characterized by the robust and unrestrained participation of hundreds of thousands of wandering fairgoers. ${ }^{\text {93 }}$ The restriction, Brennan concluded, was "not narrowly drawn to advance the State's interests, and for that reason is unconstitutional. ${ }^{.94}$

Finally, in Members of the City Council v. Taxpayers for Vincent, ${ }^{95}$ Brennan dissented from the Court's holding that a city constitutionally could prohibit the posting of signs on all public property. At the outset, Brennan observed that the posting of signs is "a timehonored" and "particularly valuable" means of communicating because "it entails a relatively small expense in reaching a wide audience, allows flexibility in accommodating various formats ... and conveys its message in a manner that is easily read and understood. ${ }^{n 6}$ This means of expression, Brennan maintained, is "'essential to the poorly financed causes of little people," $" 97$ and its prohibition should be sustained only "if the government proves that the ban ... furthers a substantial government objective, and ... constitutes the least speech-restrictive means of achieving that objective." 98 Criticizing the Court for failing "to consider carefully" whether the city's "supposed commitment" to "eradicating "visual clutter" was "genuine," Brennan argued that "such statements of aesthetic objectives should be accepted as substantial . . . only if the government demonstrates that it is pursuing an identified objective seriously and comprehensively and in ways that are unrelated to the restriction of speech."100 Because there was "no indication that the City [had] addressed its visual clutter problem in

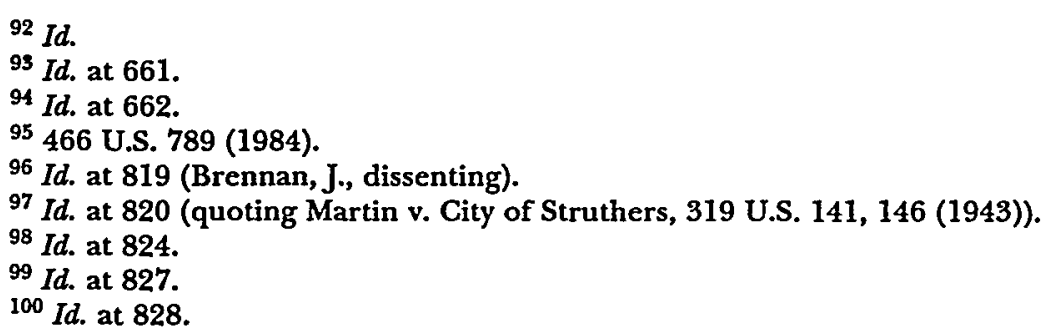


any other way than by prohibiting the posting of signs, ${ }^{\text {101 }}$ Brennan concluded that the "total ban sweeps so broadly and trenches so completely on [the] use of an important medium of political expression that it must be struck down as violative of the First Amendment." 102

Justice Brennan's public forum jurisprudence called for a "flexible approach." 103 He consistently resisted the Court's effort to pigeonhole public forum analysis ${ }^{104}$ and repeatedly challenged the Court's use of such artificial and often incoherent categories as "quintessential," "limited," and "non" public fora. ${ }^{105}$ In Brennan's view, such formulae served only "to obfuscate rather than clarify the issues." 106 Moreover, Brennan consistently chided the Court for its "insensitivity"107 to the need for a broad conception of the public forum and its "cursory ... oversight"108 of the interests asserted by government. Brennan's own conception of the public forum-that in all cases the "crucial question is whether the manner of expression is basically incompatible with the normal activity of a particular place at a particular time ${ }^{\text {109 }}$-offered a generous vision of the right. In Brennan's view, a robust "marketplace of ideas" necessarily presupposes an expansive public forum right that guarantees access to a broad range of nonmainstream means of communication for the expression of unpopular and unorthodox ideas and opinions. As Brennan well understood, such an expansive approach is essential if we are to assure the breadth, diversity, and richness of the system of free expression.

101 Id. at 829.

102 Id. at 831 .

103 See Greer v. Spock, 424 U.S. 828, 859-60 (1976) (Brennan, J., dissenting).

104 See Members of the City Council v. Taxpayers for Vincent, 466 U.S. 789, 818 (1984) (Brennan, J., dissenting).

105 See, e.g., Perry Educ. Ass'n v. Perry Local Educators' Ass'n, 460 U.S. 37, 45-46 (1983) (utilizing such "incoherent" categories).

106 United States v. Kokinda, 110 S. Ct. 3115, 3127 (1990) (Brennan, J., dissenting).

107 Taxpayers for Vincent, 466 U.S. at 818 (Brennan, J., dissenting).

108 Id. at 827.

${ }^{109}$ Grayned v. Gity of Rockford, 408 U.S. 104, 116 (1972). This language from Justice Marshall's opinion for the Court in Grayned resonates in the opinions of Justice Brennan. See, e.g., Greer v. Spock, 424 U.S. 828, 860 (1976) (Brennan, J., dissenting) (" $[\mathrm{W}] \mathrm{ith}$ the rigid characterization of a given locale as not a public forum, there is the danger that certain forms of public speech at the locale may be suppressed, even though they are basically compatible with the activities otherwise occurring at the locale."). 
If there is a bedrock principle underlying the First Amendment, it is that the Government may not prohibit the expression of an idea simply because society finds the idea itself offensive or disagreeable. 110

Near the end of his tenure, Justice Brennan faced one of the most controversial, emotional, and divisive issues he was to confront as a Justice. Not surprisingly, he addressed the issue with clarity of vision and strong commitment to the freedom of speech.

At the 1984 Republican National Convention, Gregory Lee Johnson burned an American flag to express his opposition to government policy. He was prosecuted and convicted of violating a Texas statute that prohibited any person from desecrating the flag. The statute defined "desecrating" as physically mistreating the flag in a way that the actor "knows will seriously offend" others. ${ }^{111}$ The Court invalidated Johnson's conviction in a bitterly divided fiveto-four decision, with Justice Brennan writing the opinion. ${ }^{112}$

After establishing that Johnson's burning of the American flag was "sufficiently imbued with elements of communication' to implicate the First Amendment,"113 Brennan turned to the claim that the State's interest in preventing breaches of the peace justified Johnson's conviction. In rejecting this claim, Brennan made clear that government may "not assume that every expression of a provocative idea will incite a riot."114 To the contrary, government may act only in accord with narrowly drawn and precise regulations, and even highly provocative expression may not be restricted on this basis unless it "is directed to inciting or producing imminent lawless action and is likely to incite or produce such action."115 Brennan also rejected the state's argument that Johnson's conduct fell within the "fighting words" doctrine. Embracing a narrow construction of that doctrine, reminiscent of his approach to libel in New York Times, Brennan explained that Johnson's act was not within the purview of the fighting words doctrine because "no reasonable onlooker would have regarded Johnson's generalized expression of dissatisfaction with the policies

110 Texas v. Johnson, 109 S. Ct. 2533, 2544 (1989).

111 Id. at 2543 n.7.

112 See id. at 2533.

113 Id. at 2540 (citation omitted) (quoting Spence v. Washington, 418 U.S. 405, 409 (1974)).

114 Id. at 2542.

${ }^{115}$ Id. (quoting Brandenburg v. Ohio, 395 U.S. 444, 447 (1969)). 
of the Federal Government as a direct personal insult or an invitation to exchange fisticuffs. ${ }^{\text {116 }}$

Finally, Brennan turned to the State's asserted "interest in preserving the flag as a symbol of nationhood and national unity." 117 Although conceding the legitimacy of this interest, Brennan explained that the objection was not to the State's ends, but to its means of achieving them. Because the Texas law was "not aimed at protecting the physical integrity of the flag in all circumstances," but at protecting "it only against impairments that would cause serious offense to others," Johnson's "political expression was restricted because of the content of the message he conveyed."118 In such circumstances "the State's asserted interest in preserving the special symbolic character of the flag" must be subjected "to "the most exacting scrutiny.' 119

Undertaking such scrutiny, Brennan invoked the "enduring lesson" of the Court's prior decisions: "Government may not prohibit expression simply because it disagrees with its message." 120 The Court had "never before ... held that the Government may ensure that a symbol be used to express only one view of that symbol or its referents, ${ }^{121}$ and Brennan was not about to breach that wall in Johnson, for "[t]o conclude that the Government may permit designated symbols to be used to communicate only a limited set of messages would be to enter territory having no discernible or defensible boundaries. ${ }^{122}$

In an eloquent peroration, Brennan concluded by observing that the decision in Johnson "is a reaffirmation of the principles of freedom and inclusiveness that the flag best reflects, and of the conviction that our toleration of criticism such as Johnson's is a sign and source of our strength." ${ }^{123}$ In a sharp response to the dissenters, Brennan added that "[w]e do not consecrate the flag by punishing its desecration, for in doing so we dilute the freedom that this cherished emblem represents." 124

117 Id.

${ }^{118} I d$. at 2543.

${ }^{119}$ Id. (quoting Boos v. Barry, 485 U.S. 312, 321 (1988)).

$120 I d$. at 2546.

${ }^{121} \mathrm{Id}$.

122 Id.

123 Id. at 2547.

${ }^{124}$ Id. at $2547-48$. 
By resisting the temptation to erode fundamental first amendment principles concerning the hostile audience, fighting words, and content discrimination in order to "justify" the suppression of Johnson's concededly offensive expression, Brennan's opinion in Johnson reaffirmed and solidified those principles in the most trying of circumstances. In so doing, Johnson made a profoundly important contribution to our first amendment jurisprudence.

Johnson did not, however, end the controversy over flag burning. To the contrary, the decision provoked a frenzy of protest, and immediately after the decision was announced President Bush called for a constitutional amendment to overrule Johnson. Shortly thereafter, Congress, partly in an effort to forestall such an amendment, enacted the Flag Protection Act of 1989. ${ }^{125}$ This Act, which was designed to avoid the particular defects of the Texas law, proscribed any conduct "that damages or mistreats a flag, without regard to the actor's motive, his intended message, or the likely effects of his conduct on onlookers." ${ }^{126}$ The following term, Brennan's last as a Justice, the Court, again bitterly divided, invalidated the Flag Protection Act of 1989. Justice Brennan wrote the opinion of the Court. ${ }^{127}$

Brennan gave the government's argument short shrift. Although conceding that the Act contained "no explicit content-based limitation," Brennan observed that "it is nevertheless clear that the Government's asserted interest is 'related to the suppression of free expression," for "the Government's desire to preserve the flag as a symbol for certain national ideals is implicated 'only when a person's treatment of the flag communicates [a] message' to others that is inconsistent with those ideals." ${ }^{128}$ Thus, although "Congress cast the Flag Protection Act in somewhat broader terms than the Texas statute at issue in Johnson," it ultimately "suffers from the same fundamental flaw: it suppresses expression out of concern" for its message. ${ }^{129}$

Brennan declined in Eichman to accept "the Government's invitation to reassess" the conclusion that flag burning is protected first amendment expression "in light of Congress' recent recognition of a purported 'national consensus' favoring a prohibition on

12518 U.S.C. $\$ 700$ (1988), amended by Pub. L. No. 101-31, 103 Stat. 777 (1989).

126 United States v. Eichman, 110 S. Ct. 2404, 2408 (1990).

127 See id. at 2404.

${ }^{128} I d$. at 2408 (quoting Texas v. Johnson, 109 S. Ct. 2539, 2547, 2546 (1989)).

${ }^{129}$ Id. at 2409. 
flag-burning," for even "assuming such a consensus exists, any suggestion that the Government's interest in suppressing speech becomes more weighty as popular opposition to that speech grows is foreign to the First Amendment." ${ }^{\text {130 }}$

Radical shifts in judicial doctrine are rare. They usually occur over long periods step-by-step in a series of decisions. "The complex phenomenon which lawyers know as law is an always unfinished product. It may be compared to a tapestry the weaving of which is never done . . ."131

It is possible in an essay of this nature to mention only a few of the areas in which Justice Brennan contributed to our first amendment jurisprudence. I have not discussed his efforts, for example, in the areas of patronage, ${ }^{132}$ prior restraint, ${ }^{133}$ charitable solicitation, ${ }^{134}$ commercial advertising, ${ }^{135}$ overbreadth, ${ }^{136}$ nonobscene but sexually explicit expression, ${ }^{137}$ freedom of the press, ${ }^{138}$ residential picketing, ${ }^{139}$ the removal of books from libraries, ${ }^{140}$ and a host of other important first amendment areas. What is clear, however, is that Justice Brennan was a product of the controversies that often divided the nation during his tenure on the Court. His unique understanding of the freedom of speech was shaped by those controversies and he, in turn, gave those controversies direction and helped the nation resolve them.

180 Id.

131 Brennan, The Supreme Court and the Meiklejohn Interpretation of the First Amendment, 79 HARV. L. REv. 1, 10 (1965) (quoting O'Meara, The Notre Dame Program: Training Skilled Craftsmen and Leaders, 49 A.B.A.J. 614, 670 (1957)).

132 See Rutan v. Republican Party of Illinois, 110 S. Ct. 2729 (1990); Elrod v. Burns, 427 U.S. 347 (1976).

${ }^{138}$ See City of Lakewood v. Plain Dealer Publishing Co., 486 U.S. 750 (1988);

Freedman v. Maryland, 380 U.S. 51 (1965).

${ }^{134}$ See Riley v. National Fed'n of the Blind, 487 U.S. 781 (1988).

135 See Shapero v. Kentucky Bar Ass'n, 486 U.S. 466 (1988); Posadas de Puerto Rico Ass'n v. Tourism Co., 478 U.S. 328 (1986) (Brennan, J., dissenting); Carey v. Population Servs. Int'l, 431 U.S. 678 (1977).

136 See City of Houston v. Hill, 482 U.S. 451 (1987); Gooding v. Wilson, 405 U.S. 518 (1972).

137 See City of Renton v. Playtime Theatres, 475 U.S. 41 (1986) (Brennan, J., dissenting); FCC v. Pacifica Found., 438 U.S. 726 (1978) (Brennan, J., dissenting); Young v. American Mini Theatres, 427 U.S. 50 (1976) (Brennan, J., dissenting).

${ }^{138}$ See FCC v. League of Women Voters, 468 U.S. 364 (1984); Globe Newspaper Co. v. Superior Court, 457 U.S. 596 (1982).

${ }^{139}$ See Frisby v. Schultz, 487 U.S. 474 (1988) (Brennan, J., dissenting); Carey v. Brown, 447 U.S. 455 (1980).

${ }^{140}$ See Board of Educ. v. Pico, 457 U.S. 853 (1982). 
Several themes emerge from Justice Brennan's first amendment jurisprudence: procedural regularity, narrow specificity, toleration, chilling effect, overbreadth, diversity, self-governance, and the like. These themes are familiar. They are familiar because Justice Brennan made them so. There can be little doubt that Justice Brennan stands alongside Justices Holmes, Brandeis, Black, and Douglas as one of the staunchest defenders of the freedom of speech our nation has ever known. They are in good company. 
HeinOnline -- 139 U. Pa. L. Rev. 1356 1990-1991 